\title{
Non-specific X linked mental retardation with aphasia exhibiting genetic linkage to chromosomal region Xp11
}

\author{
Golder N Wilson, C Sue Richards, Kathy Katz, Gail S Brookshire
}

\begin{abstract}
A new type of non-specific $X$ linked mental retardation is described in a three generation family. The three affected males had severe mental retardation (IQ 20 to 30 ), mutism, growth failure, frequent infections, seizures, and the following minor anomalies: brachycephaly, frontal hair whorl, square face, large mouth, thick lips, and prognathism. There was not a characteristic facies. Normal laboratory studies on the proband included a karyotype with fragile $X$ screening, skeletal survey, blood amino acid, urine organic acid, and HGPRT levels. Linkage analysis was performed with $10 \mathrm{X}$ chromosome DNA probes of which probe $D X S 255$ at chromosomal region Xp11.22 gave a maximal two point lod score of $2 \cdot 10$ if phase was inferred and $1 \cdot 20$ if it was not. Crossovers were shown with probes mapping to regions $X$ p22, $X p 21$, and Xq28. Comparison of these patients with $80 \mathrm{X}$ linked causes of mental retardation, including 41 which might be classified as 'non-specific', showed no other disorders compatible with the phenotypic and linkage data.

(f Med Genet 1992;29:629-34)
\end{abstract}

It is ironic that the human $\mathrm{X}$ chromosome, noted for its conservation in mammalian evolution, should wreak such havoc upon the mental function of hemizygous persons. Genes on the $\mathrm{X}$ chromosome may account for about a third of mental retardation in males ${ }^{1}$ and numerous surveys document a 20 to $50 \%$ excess of males over females when selected for severe retardation. ${ }^{2}$ While disorders such as the Lowe and Lesch-Nyhan syndromes are associated with definitive morphological or metabolic findings which aid delineation, many subjects with $\mathrm{X}$ linked mental retardation do not have striking phenotypes. These disorders have been grouped under the term 'non-specific' X linked mental retardation (XLMR) and have a cumulative incidence greater than 1 to 2 per 1000 male births. ${ }^{2}$ Over 30 types of XLMR have now been defined and many have been mapped to specific regions of the $\mathrm{X}$ chromosome (fig 1). ${ }^{12}$ Here we describe a new variety of XLMR which exhibits striking aphasia and linkage to the Xp11 region.

\section{Case reports}

Case 1 (IV.1, fig 2) was referred for evaluation at 15 months of age because of developmental delay. The height was $81 \mathrm{~cm}$ (75th centile), weight $11 \mathrm{~kg}$ (50th centile), and head circumference $46 \mathrm{~cm}$ (25th centile). At birth the patient weighed $3100 \mathrm{~g}$ with Apgar scores of 7 and 9 after a 37 week gestation to a 26 year old primigravida. There was hypertension and 'flu' in the last trimester, when antepartum amniocentesis to determine the $\mathrm{L} / \mathrm{S}$ ratio showed meconium. After caesarian section, the
Department of Pediatrics, University of Texas,

Southwestern Medical Center, 5323 Harry Hines Blvd, Dallas, Texas 75235-9063, USA.

G N Wilson

C S Richards

G S Brookshire

Gene Screen, 2600

Stemmons Fwy,

Dallas, Texas, USA.

C S Richards

K Katz

Correspondence to Professor Wilson.

Received 16 January 1992 Revised version accepted 24 February 1992

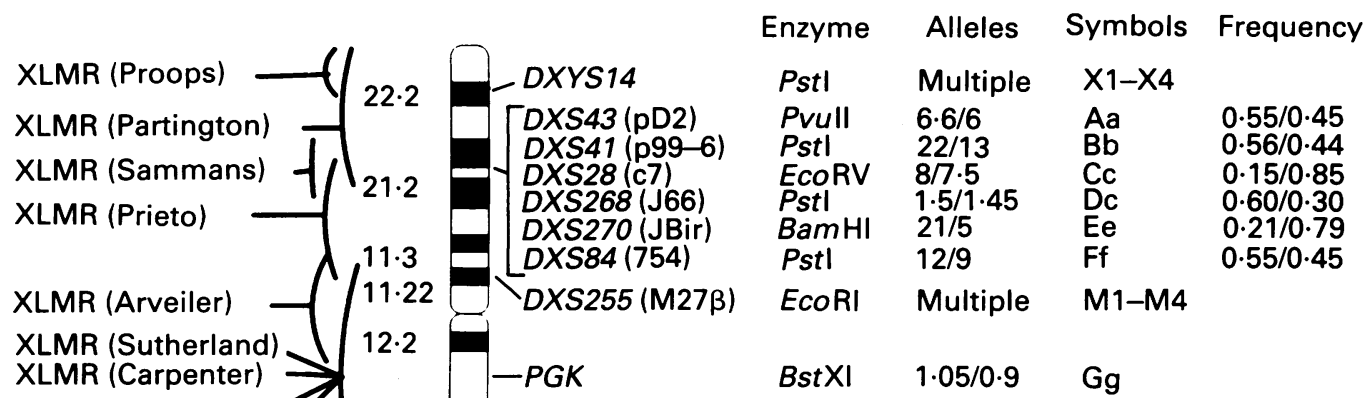

Bcll $\quad 1 \cdot 2 / 0.9 \quad \mathrm{Hh}$

$0 \cdot 71 / 0 \cdot 29$

Figure 1 Idiogram of the human $X$ chromosome showing the locations of mapped XLMR loci. ${ }^{3}$ The locations of informative DNA probes along with RFLP fragment sizes, allele designations, and frequencies in the general population are also shown. 


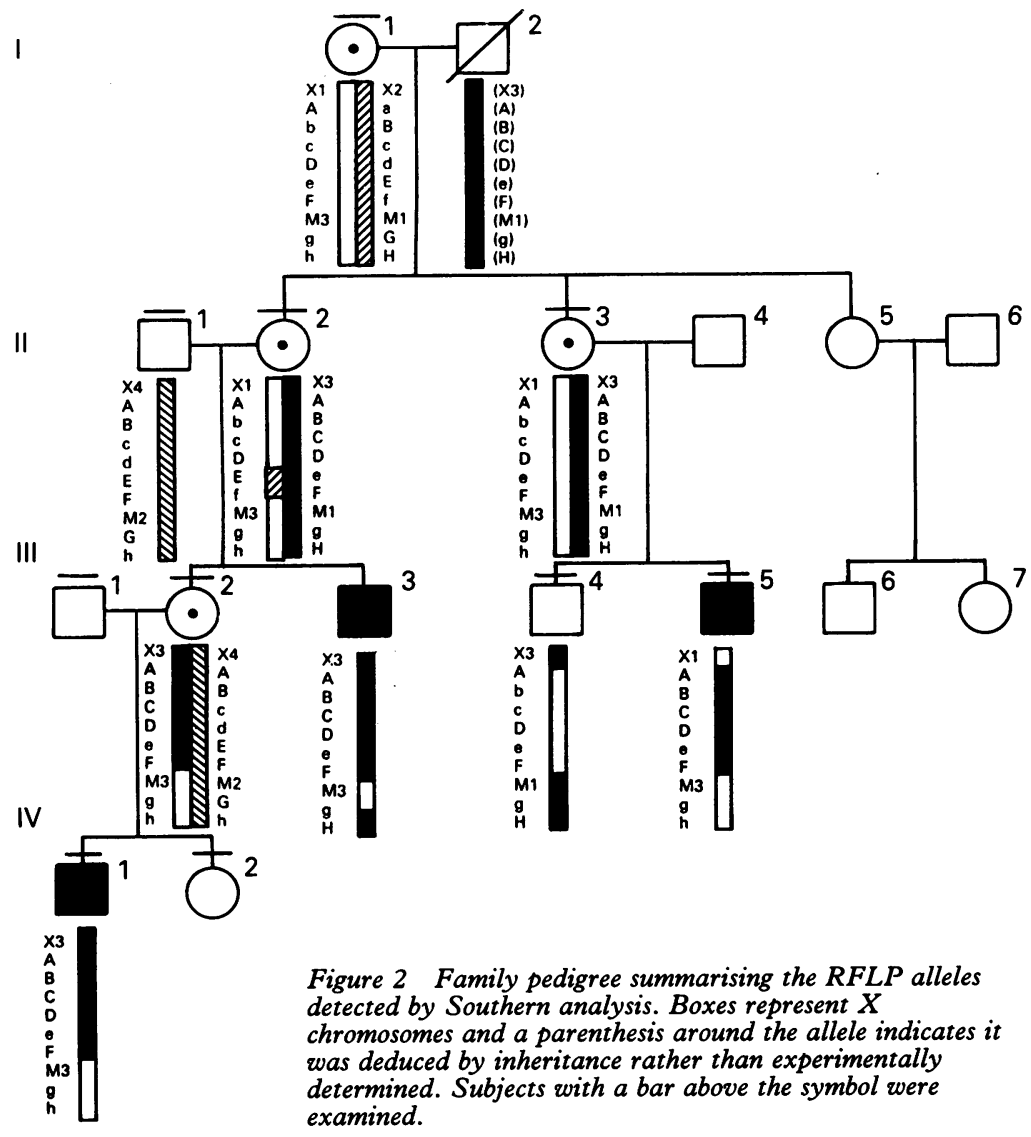

child was hypotonic and suffered from meconium aspiration. The mother immediately recognised a frontal hair whorl identical to that of her affected brother. Early developmental milestones were delayed and a single tonicclonic seizure occurred at 10 months accompanied by a transient left hemiparesis. An MRI scan performed at that time showed an increased periventricular signal, delayed myelination, and slightly prominent lateral ventricles. Physical examination at 16 months (fig $3 \mathrm{H})$ showed lip smacking, tongue thrusting, and self-stimulating behaviour with the minor anomalies listed in table 1. Laboratory findings included normal karyotype with fragile $\mathrm{X}$ analysis; normal haematological, thyroid, and liver functions; normal serum amino acids, urine organic acids, and urine mucopolysaccharides; normal skeletal survey; and normal levels of the enzyme HGPRT (1119 U/mg with controls of 635 and 938). Follow up examination at 3 years showed a developmental level of about 16 months with a vocabulary of five to 10 words.

Case 2 (III.5, fig 2) is 16 years old and lives in a developmental centre. Birth weight was $3150 \mathrm{~g}$ after an uncomplicated term pregnancy and a breech delivery with Apgar scores of 8 and 8. A 'peculiar' face was mentioned at birth and infancy was complicated by pylorospasm and frequent upper respiratory infections. He was hypotonic during infancy with frequent self-stimulating behaviour and intractable crying spells. Walking started at the age of $10 \frac{1}{2}$ years. Medical problems in childhood included chronic otitis, sinusitis, bilateral inguinal hernias, and a bowel biopsy for
Hirschsprung disease which was reportedly negative despite continued administration of laxatives. Developmental delay was recognised at 1 year and an eventual IQ of less than 30 was measured. The patient can imitate sounds, understand his name and simple commands, knows limited sign language, has mild myopia, and normal hearing, and no speech. Care givers describe a limited attention span, cold and reddened extremities, rhythmic breathing, frequent tongue protrusion with licking and tasting of objects, an expressionless face, and a good natured demeanour. Physical examination showed an extremely withdrawn and 'autistic' adolescent with the abnormalities listed in table 1 . His height was $145 \mathrm{~cm}$ (below the 3 rd centile, 50th centile for $11 \frac{1}{2}$ years), weight $27 \mathrm{~kg}$ (below the $3 \mathrm{rd}$ centile, 50 th centile for 9 years), and head circumference $50 \mathrm{~cm}$ (below the 3rd centile, 50th centile for 3 years). Photographs at ages 8 months, $3 \frac{1}{2}$ years, and 9 years are shown in fig $3 E-G$, respectively. Normal laboratory findings included karyotype, serum amino acids, CBC and electrolytes, and SMAC 20 serum screen including hepatic enzymes.

Case 3 (III.3, fig 2) is 27 years old and resides in a state school for the retarded. Birth weight was $3650 \mathrm{~g}$ after a long labour; hypotonia, somnulence, and feeding problems were noted in infancy. Frequent infections including otitis and pneumonia occurred in early childhood. Developmental delay was recognised by the age of 6 months, with an IQ of 40 being measured in adulthood. He has inappropriate behaviour with self-injury and resistance requiring occasional constraints. This behaviour has improved somewhat on Tegretol $^{R}$, Serentil ${ }^{R}$, and Artane ${ }^{R}$ therapy for a diagnosis of organic brain disorder, mixed type (DSM-IIR). The patient can dress himself and maintain personal hygiene, function in a sheltered workshop, count up to 10 objects, but cannot handle small sums of money or keep a locker key. He is completely mute, has mild myopia, excellent comprehension of instructions, a 50 word vocabulary in sign language, and normal hearing. Much of his spare time is spent listening to the radio. Physical examination disclosed an extremely curious, interactive, and friendly young man with the minor anomalies listed in table 1 . His height was $163 \mathrm{~cm}$ (5th centile), weight $57 \mathrm{~kg}$ (20th centile), and head circumference $54.5 \mathrm{~cm}$ (25th centile). His appearance is shown at ages 6 months, 14 years, and 27 years in fig $3 A-D$. Laboratory studies included normal karyotype with fragile $\mathrm{X}$ screening, normal serum amino acids, and normal haematological and liver functions.

The carrier females II.1, II.3, and III.2 (fig 2) were all examined and found to have normal intellectual function without evidence of dysmorphology.

\section{Methods}

\section{DNA BANKING}

Heparinised blood samples from family members were collected in Leucoprep ${ }^{\mathrm{TM}}$ tubes, 

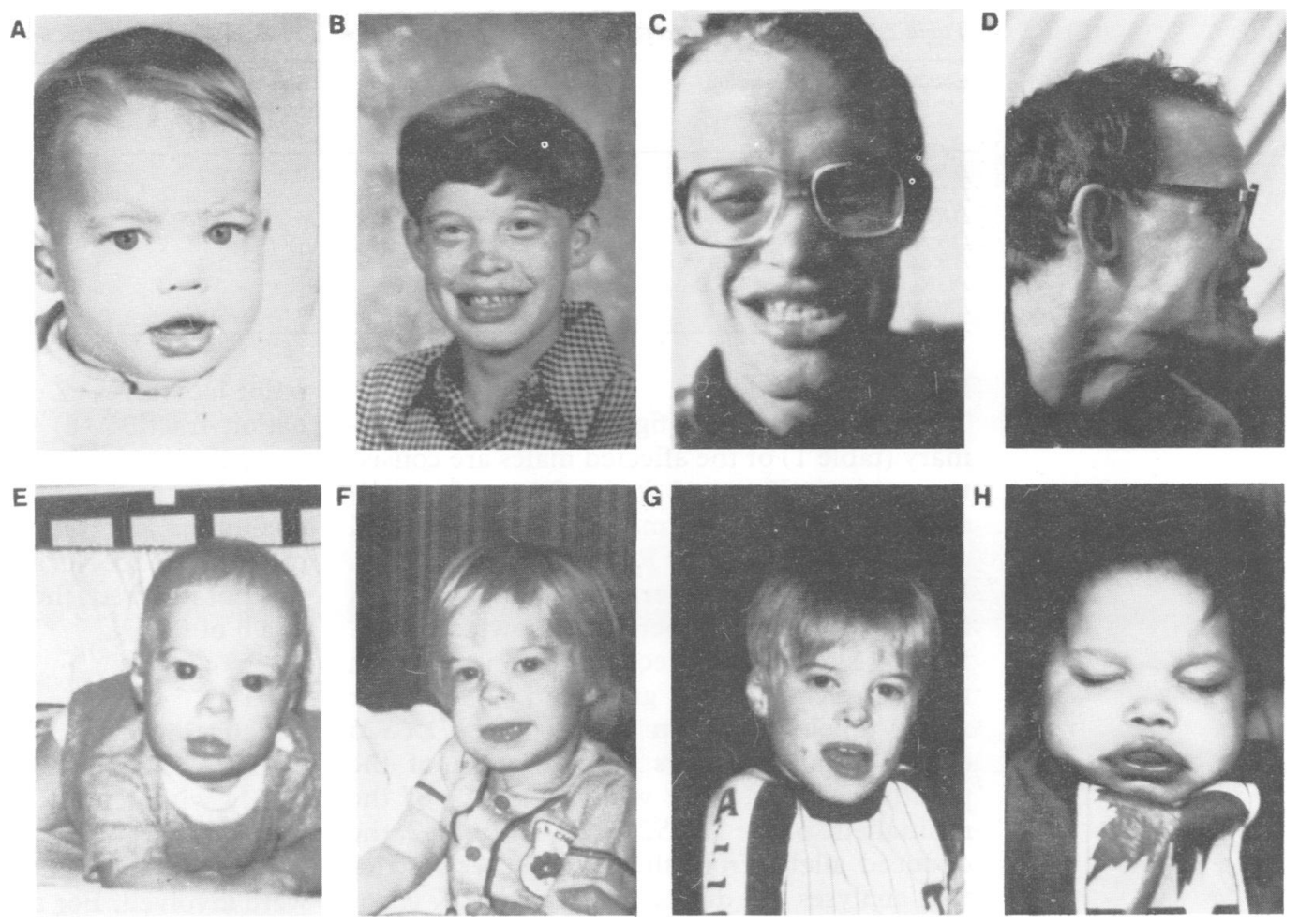

Figure 3 Affected males III.3 ( $A, 16$ months, B, 14 years, $C, D, 27$ years), III.5 (E, 8 months, F, 3 years, G, 9 years), and IV.1 (H, 10 months) as designated in fig 2.

centrifuged for 15 minutes at 1500 to $1800 \mathrm{~g}$ at room temperature, and the washed white cells (two $5 \mathrm{ml}$ aliquots) incubated with equal volumes of supernatant medium (RPMI 1640 and $10 \%$ fetal calf serum, GIBCO) from an EB virus infected marmoset cell line. Phytohaemagglutinin $(0 \cdot 1 \mathrm{ml}$ of GIBCO suspension) was added to both cultures followed by incubation for three to five days at $37^{\circ} \mathrm{C}$ in $5 \% \mathrm{CO}_{2}$. After successful transformation was indicated by visible cell aggregates, the lymphoblast cultures were expanded by decanting and replacing with fresh medium. The lymphoblast pellet from $100 \mathrm{ml}$ of culture was washed with $0.9 \% \mathrm{NaCl}$; hand homogenised in $5 \mathrm{ml}$ of $50 \mathrm{mmol} / 1$ Tris- $\mathrm{HCl}, \mathrm{pH} 7 \cdot 5,25 \mathrm{mmol} / 1 \mathrm{KCl}$, $5 \mathrm{mmol} / 1 \mathrm{MgCl}_{2}, 0.25 \mathrm{~mol} / 1$ sucrose, $0.01 \%$ Triton X-100; incubated for 15 minutes at $4^{\circ} \mathrm{C}$ to accomplish cell lysis; and extracted by the procedure of Marmur. ${ }^{4}$ From $500 \mu \mathrm{g}$ to $1 \mathrm{mg}$

Table 1 Clinical manifestations of affected males.

\begin{tabular}{lcccc}
\hline & IV.1 & III.3 & III.5 & Total \\
\hline Age (y) & 3 & 27 & 16 & \\
Severe MR (IQ) & $(<50)$ & $(<30)$ & $(<30)$ & $3 / 3$ \\
Growth failure & - & + & + & $2 / 3$ \\
Microcephaly & - & + & + & $1 / 3$ \\
Brachycephaly & + & + & + & $3 / 3$ \\
Frontal whorl/upsweep & + & + & + & $3 / 3$ \\
Square jaw & + & + & + & $3 / 3$ \\
Hypertelorism & + & + & + & $2 / 3$ \\
Thick lips & + & + & + & $3 / 3$ \\
Large mouth & + & + & + & $3 / 3$ \\
Tongue thrusting & + & + & + & $3 / 3$ \\
Prognathism & + & + & + & $2 / 3$ \\
Inguinal hernia/hydrocele & + & + & + & $3 / 3$ \\
Seizures & + & + & $?$ & $1 / 1$ \\
Frequent infections & + & $?$ & & +
\end{tabular}

of DNA was obtained after chloroform extraction, RNase and Pronase treatment, and ethanol spooling. DNA was stored frozen before use.

\section{DNA ANALYSIS AND LINKAGE STUDIES}

The DNA probe $D X Y S 14$ was obtained from Lifecodes Corporation (New York), ${ }^{45}$ DXS43, $D X S 41$, and $D X S 270$ from L Kunkel, ${ }^{6-8}$ $D X S 28$ from J Mandel, DXS268 and DXS84 from $\mathrm{G}$ van Ommen, ${ }^{9} D X S 255$ from I Craig and $\mathrm{Y}$ Boyd, ${ }^{10} P G K$ from B Vogelstein, ${ }^{11}$ and F8C from the Human Mutant Cell Repository, catalogue no 57204. Cloned DNA segments were separated from vector segments on $0.8 \%$ agarose minigels and purified using GeneClean (Bio 101 Inc, La Jolla CA). For RFLP analysis, 5 to $10 \mu \mathrm{g}$ of DNA was restricted using the manufacturer's protocol and excess enzyme. DNA transfer to Hybond $\mathrm{N}+$ membranes (Amersham) was accomplished by capillary action after electrophoresis on $\mathbf{0 . 8 \%}$ agarose gels and alkali denaturation/neutralisation. Prehybridisation, hybridisation, and washing procedures were undertaken using the conditions of Church and Gilbert ${ }^{12}$ with $50 \mathrm{ng}$ of DNA segment labelled to a specific activity of $10^{9} \mathrm{cpm} / \mu \mathrm{g}$ with ${ }^{32} \mathrm{P}-\mathrm{dCTP}$ by random hexanucleotide primer extension. ${ }^{13}$ Washed membranes were exposed to Kodak $x$ ray film for one to two days at $-70^{\circ} \mathrm{C}$ using an intensifying screen. Of the $10 \mathrm{X}$ linked probes used (fig 1), seven gave informative results as displayed in table 2. Two point lod scores $(\mathrm{Z})$ were calculated using the program MLINK as described by Ott. ${ }^{14} 15$ 
Table 2 Pair wise lod scores; putative XLMR gene versus $X$ chromosome marker loci.

\begin{tabular}{|c|c|c|c|c|c|c|c|c|c|}
\hline \multirow[t]{2}{*}{ Locus } & \multirow[t]{2}{*}{ Location } & \multicolumn{6}{|c|}{$\mathrm{Z}$ at $\theta$ of } & \multirow[t]{2}{*}{$\hat{\theta}$} & \multirow[t]{2}{*}{$\hat{\mathbf{z}}$} \\
\hline & & 0.001 & 0.01 & $0 \cdot 1$ & $0 \cdot 2$ & 0.3 & 0.4 & & \\
\hline $\begin{array}{l}\text { DXY14 } \\
D X S 43 \\
D X S 41 \\
D X S 28 \\
D X S 255 \\
P G K \\
F 8 C\end{array}$ & $\begin{array}{l}\text { Xp22.2 } \\
\text { Xp21 } \\
\text { Xp21 } \\
\text { Xp21 } \\
\text { Xp11.22 } \\
\text { Xq13 } \\
\text { Xq28 }\end{array}$ & $\begin{array}{c}-3.9 \\
0.30 \\
-4 \cdot 1 \\
-9.9 \\
2.1 \\
-7.8 \\
-4.1\end{array}$ & $\begin{array}{c}-1 \cdot 9 \\
0 \cdot 30 \\
-2 \cdot 2 \\
-5 \cdot 9 \\
2 \cdot 1 \\
-4 \cdot 8 \\
-2 \cdot 2\end{array}$ & $\begin{array}{c}-0.12 \\
0.26 \\
-0.38 \\
-2.0 \\
1.8 \\
-1.8 \\
-0.38\end{array}$ & $\begin{array}{c}0.22 \\
0.20 \\
0.020 \\
-0.98 \\
1.4 \\
-0.99 \\
0.02\end{array}$ & $\begin{array}{c}0.29 \\
0.15 \\
0.14 \\
-0.45 \\
1.1 \\
-0.52 \\
0.15\end{array}$ & $\begin{array}{r}0.20 \\
0.08 \\
0.12 \\
-0.15 \\
0.56 \\
-0.21 \\
0.08\end{array}$ & $\begin{array}{l}0 \cdot 3 \\
0 \cdot 001 \\
0 \cdot 3 \\
0 \cdot 4 \\
0 \cdot 001 \\
0 \cdot 4 \\
0 \cdot 3\end{array}$ & $\begin{array}{r}0.29 \\
0.30 \\
0.14 \\
-0.15 \\
2.1 \\
-0.21 \\
0.14\end{array}$ \\
\hline
\end{tabular}

Results

The family pedigree (fig 2) and clinical summary (table 1) of the affected males are consistent with an $\mathrm{X}$ linked form of mental retardation which could be mapped to a specific $X$ chromosome region by RFLP linkage analysis. Representative Southern analyses of DNA from 11 family members are shown in fig 4 . Fig 4A shows three recombinations between the putative XLMR gene and the smaller $E c o$ RV allele (c) shown by the probe $D X S 28$ (fig 1). Fig 4B shows cosegregation of the putative XLMR gene with allele M3 of the multiallelic probe DXS255 (fig 1). In fig 2, the deduced alleles from these and other restriction analyses are displayed alongside $\mathrm{X}$ chromosomes of family members. The marker haplotypes were deduced assuming a minimum number of crossovers and implied that recombinations were shown by the DNA probes $D X S 14$ (alleles X1 to X4), DXS28 (alleles C, c), and $F 8 C$ (alleles $\mathrm{H}, \mathrm{h}$ ). Table 2 shows two
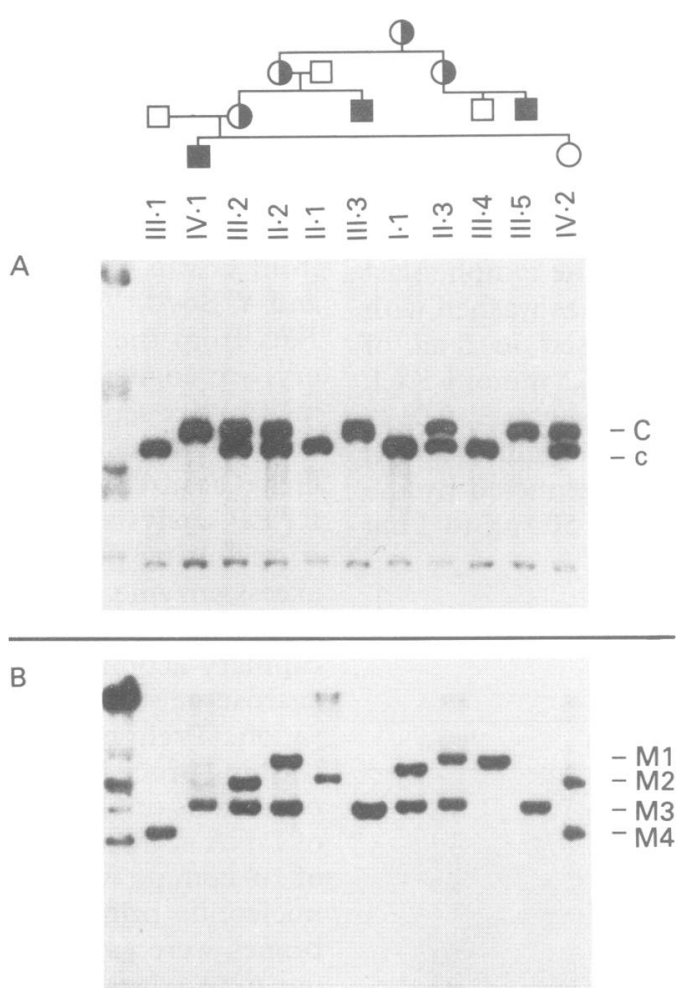

Figure 4 Representative Southern blots showing (A) 8 and $7.5 \mathrm{~kb} R F L P$ alleles $(C, c)$ detected with the enzyme EcoRV and DNA probe DXS28, (B) alleles $M 1-M 4$ detected with the enzyme EcoRI and DNA probe DXS255. Lane numbers correspond to the subjects in fig 2 as shown by the condensed pedigree. point lod scores $(Z)$ as a function of recombination fraction $(\theta)$ with phase inferred from the pedigree and marker configuration. The maximal two point lod score $(\hat{Z})$ was $2 \cdot 10$ at a recombination fraction of 0.01 for the DNA

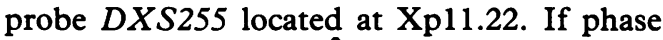
was not inferred, then $\hat{Z}$ for $D X S 255$ was 1.20 at a $\hat{\theta}$ of 0 .

\section{Discussion}

In 1943, Martin and Bell ${ }^{16}$ first described a family with XLMR. Two additional families with XLMR were soon reported, ${ }^{17} 18$ raising the question of whether one or many genes were involved. For a time, all types of XLMR were named 'Martin-Bell syndrome' or 'Renpenning syndrome' after the authors of these first descriptions. This confusion began to lessen when a more specific phenotype of prominent jaw, large ears, lax connective tissue, and megalotestes was delineated for the Martin-Bell syndrome. Soon it was recognised that most patients with this phenotype had a fragile $\mathrm{X}$ marker which could be shown by culture of lymphocytes or fibroblasts in folate deficient medium. Improved analysis and widespread screening has now shown that the fragile $\mathrm{X}$ syndrome affects about 1 in 1000 males and accounts for most patients with Martin-Bell phenotype as well as 30 to $40 \%$ of families with XLMR. ${ }^{2}$

Review of the catalogue of genetic disorders updated periodically by McKusick ${ }^{19}$ shows 60 $\mathrm{X}$ linked conditions which cause mental retardation, many with distinctive associated features. An estimated 21 of these disorders (depending on the perspective of the reviewer) have been placed in the category of 'nonspecific X linked mental retardation (XLMR)', that is, mental retardation without a striking metabolic or morphological phenotype. Recent surveys ${ }^{120}$ list an additional 20 conditions with XLMR defined in single families which have not been assigned a McKusick number. In many of these conditions classified as XLMR, careful assessment can establish a syndrome which allows separation from 'true' XLMR with normal appearance. Differentiating clinical features include a characteristic facies (Prieto XLMR, ${ }^{21}$ Atkin-Flaitz XLMR, ${ }^{22}$ Chudley-Lowry-Hoar XLMR, ${ }^{23}$ Pettigrew XLMR, ${ }^{24}$ Vasquez XLMR ${ }^{25}$ ), palmoplantar hyperkeratosis (Fitzsimmons XLMR ${ }^{26}$ ), macrotestes without fragile $\mathrm{X}$ (Clark-Baraitser $\mathrm{XLMR},{ }^{27}$ Tranebjaerg II XLMR, ${ }^{28}$ Tariverdian $X^{2} M^{29}$ ), Marfanoid habitus (LujanFryns $\mathrm{XLMR}^{30}$ ), and skeletal dysplasia (Chris\left. tian $X{ } M^{31}\right)$. Several forms of XLMR are associated with spastic paraplegia and ataxia, 
including Allan-Herndon XLMR, ${ }^{18}$ GareisMason XLMR, ${ }^{32}$ Paine-Seemanova XLMR, ${ }^{33}$ Smith-Fineman-Myers XLMR, ${ }^{34}$ Davis $\mathrm{XLMR},{ }^{35}$ and Schimke XLMR. ${ }^{36}$

In the present family, a characteristic facial appearance, metabolic abnormality, or chromosomal aberration could not be found. However, physical examination disclosed the minor anomalies listed in table 1 which suggest that this condition is different from previously reported types of XLMR. Prominent among the minor anomalies was a frontal hair whorl or upsweep; the presence of this manifestation allowed natal recognition of the condition by the proband's mother. This anomaly is found in two other types of $\mathrm{X}$ linked mental retardation, but in neither is the full spectrum of malformation compatible with that in the proband and his male relatives. The OpitzKaveggia FG syndrome ${ }^{37}$ includes a frontal cowlick with a prominent anterior fontanelle, hypertelorism, long philtrum, abnormal ears, hypotonia, agenesis of the corpus callosum, and gastrointestinal defects. The Pallister W syndrome ${ }^{38}$ includes a frontal cowlick with pugilistic facies, hypertelorism, midline notch of the upper lip, skeletal anomalies, and seizures. Comparison with the 39 other XLMR conditions showed no comparable malformation pattern either.

Linkage analysis of this family does not suggest a match with previously reported forms of XLMR. Coordinate segregation with the DNA marker DXS255 at chromosomal region Xp11.22 provided a maximal two point lod score $(\hat{Z})$ of $2 \cdot 1$ based on seven informative meioses in this family (table 2 ). Although the distal X short (p21-pter) and long arms (q28) are ruled out by crossovers, a gene location anywhere within the Xp11-Xq11 pericentromeric region would be compatible with the linkage data. Additional families with this disorder must be ascertained to refine the gene location and to provide a lod score above the value of 3 considered to establish linkage. Comparison with the $\mathrm{X}$ chromosome regions implicated in 13 other forms of XLMR ${ }^{3}$ (fig 1) indicates overlap with the Prieto, ${ }^{21}$ Carpenter, ${ }^{39}$ Sutherland, ${ }^{40}$ and Sammans ${ }^{41}$ forms of XLMR with phenotypes that are quite different from the present family. The Xpl1-q11 region is also a candidate for gene localisation in two XLMR families ${ }^{4243}$ where affected males lack even subtle anomalies. If these and the present family involve the same locus, then allelic heterogeneity or variable expressivity must be invoked to explain the different phenotypes.

The three affected males in the family were striking for their absent or delayed speech. The oldest affected subject (III.5) was particularly remarkable for aphasia despite an interactive personality and considerable facility with sign language. Speech is mentioned as delayed or abnormal in seven of the 41 XLMR disorders so far described. In one of them (Garais-Mason XLMR ${ }^{32}$ ), speech was absent while in others it was dysarthric ${ }^{18354-46}$ or described as verbal disability. ${ }^{4147}$ The severe mutism in the present family despite normal hearing suggests a gene particularly involved with speech, that is, through control of brain asymmetry/lateralisation, rather than one which merely impacts speech along with other higher cortical functions. Such associations of $\mathrm{X}$ chromosome loci and particular cognitive or behavioural traits emphasise the insights these characterised genes should bring to neural development and mental function. ${ }^{4849}$

Support of a grant from the Biological Humanics Foundation, Dallas, TX to GNW is gratefully acknowledged.

1 Arena JF, Lubs HA. Computerized approach to X-linked mental retardation syndromes. Am $f$ Med Genet mental retardacio

2 Glass IA. X linked mental retardation. $f$ Med Genet 1991;28:361-71.

3 Neri G, Gal A, Lubs HA. XLMR genes: update 1989. Am $\mathcal{F}$ Med Genet 1989;38:186-9.

4 Marmur J. A procedure for isolating DNA from microorganisms. Methods Enzymol 1963;6:726-38.

5 Cooke H, Brown W, Rappold G. Hypervariable telomeric sequences from the human sex chromosomes are pseudoautosomal. Nature 1985;317:687-92.

6 Kunkel LM, Monaco AP, Middlesworth W, Ochs HD Latt SA. Specific cloning of DNA fragments absent from the DNA of a male patient with an X chromosome deletion. Proc Natl Acad Sci USA 1985;82:4778-82.

7 Koenig M, Hoffman EP, Bertelson CJ, et al. Complete cloning of the Duchenne muscular dystrophy cDNA and preliminary genomic organization of the DMD gene in normal and affected individuals. Cell 1987;50:509-17.

8 Monaco AP, Bertelson CJ, Middleworth W, et al. Detection of deletions spanning the Duchenne muscular dystrophy locus using a tightly linked DNA segment. Nature 1985;316:842-5.

9 van Ommen GJB, Bertelson C, Ginjaar HB, et al. Longrange genomic map of the Duchenne muscular dystrophy gene: isolation and use of J66 (DXS268), a distal intragegene: isolation and use of J66 (DXS268)

10 Fraser NJ, Boyd Y, Craig I. Isolation and characterization of a human variable copy number tandem repeat at Xcenp11.22. Genomics 1989;5:144-8.

11 Vogelstein B, Fearson ER, Hamilton SR, et al. Clona analysis using recombinant DNA probes from the $\mathrm{X}$ chromosome. Cancer Res 1987;47:4806-13.

12 Church GM, Gilbert W. Genomic sequencing. Proc Nat Acad Sci USA 1984;81:1991-5.

13 Feinberg AP, Vogelstein B. A technique for radiolabeling DNA restriction endonuclease fragments to high specific activity. Anal Biochem 1983;132:6-13.

$14 \mathrm{Ott} \mathrm{J}$. A computer program for linkage analysis of genera human pedigrees. Am $\mathcal{f}$ Hum Genet 1976;28:528-9.

15 Ott J. Analysis of human genetic linkage. Baltimore: Johns Hopkins University Press, 1991.

16 Martin JP, Bell J. A pedigree of mental defect showing sexlinkage. $\mathcal{F}$ Neurol Psychiatry 1943;6:154-7.

17 Dunn HG, Renpenning H, Gerrard JW, Miller JR, Tabata $\mathrm{T}$, Federoff $\mathrm{S}$. Mental retardation as a sex-linked defect. Am $\mathcal{J}$ Ment Defic 1962;67:827-48.

18 Stevenson RE, Goodman HO, Schwartz CE, et al. AllanHerndon syndrome. I. Clinical studies. Am $\mathcal{J}$ Hum Genet 1990;47:446-53.

19 McKusick VA. Mendelian inheritance in man. Baltimore: Johns Hopkins University Press, 1990.

20 Opitz JM, Sutherland GR. Conference report. International workshop on the fragile $\mathrm{X}$ and $\mathrm{X}$-linked mental retardation. Am f Med Genet 1984;17:5-94.

21 Watty A, Prieto F, Beneyto M, Neugebauer M, Gal A Gene localization in a family with X-linked syndromal mental retardation (Prieto syndrome). Am $\mathcal{f}$ Med Genet 1991;38:234-9.

22 Atkin JF, Flaitz K, Patil S, Smith W. A new X-linked mental retardation syndrome. Am $f$ Med Genet 1985;21:697-705.

23 Chudley AE, Lowry RB, Hoar DI. Mental retardation, distinct facial changes, short stature, obesity, and hypogonadism: a new $\mathrm{X}$-linked mental retardation syndrome. Am $\mathcal{f}$ Med Genet 1988;31:741-51.

24 Pettigrew AL, Jackson LG, Ledbetter DH. A new X-linked mental retardation disorder with Dandy Walker malformental retardation disorder with Dandy Walker malfor-
mation, basal ganglia disease and seizure. Am $\mathcal{F}$ Med mation, basal ganglia
Genet $1991 ; 38: 200-7$.

25 Vasquez SB, Hurst DL, Sotos JF. X-linked hypogonadism, gynecomastia, mental retardation, short stature, and obegynecomastia, mental retardation, short stature, a
sity - a new syndrome. $\mathcal{P}$ Pediatr 1979;94:56-60.

26 Fitzsimmons JS, Fitzsimmons EM, McLachlan JI, Gilbert GB. Four brothers with mental retardation, spastic parab. Four brothers with mental retardation, spastic par-
aplegia and palmoplantar hyperkeratosis. A new synaplegia and palmoplantar hyperke
drome? Clin Genet 1983;23:329-35.

27 Clark RD, Baraitser M. A new X-linked mental retardation syndrome. Am $\mathcal{f}$ Med Genet 1987;26:13-15.

28 Tranebjaerg $L$, Lou $H$, Andresen J. A new X-linked syndrome with apraxia, ataxia and mental deficiency. Clinical cytogenetic and neuropsychiatric studies in 2 Danish families. Am $\mathcal{f}$ Med Genet 1991;38:514A. 
29 Tariverdian G, Froster-Iskenius U, Deuschl G, Wolff G. Mental retardation, acromegalic face, and megalotestes in two half-brothers: a specific form of X-linked mental retardation without $\operatorname{fra}(\mathrm{X})(\mathrm{q})$ ? Am $\mathcal{f}$ Med Genet 1991;38:208-11.

30 Lujan JE, Carlin ME, Lubs HA. A form of X-linked mental retardation with marfanoid habitus. Am f Med Genet 1984;17:311-22.

31 Christian JC, DeMyer W, Franken EA, Huff JS, Khairi S, Reed T. X-linked skeletal dysplasia with mental retardation. Clin Genet 1977;11:128-36.

32 Gareis FJ, Mason JD. X-linked mental retardation with clasp thumb anomaly. Am $\mathcal{F}$ Med Genet 1984;17:333-8.

33 Seemanova E, Lesny I, Hyanek J, et al. X-chromosome recessive microcephaly with epilepsy, spastic tetraplegia and absent abdominal reflexes. New variety of Paine syndrome? Humangenetik 1973;20:113-7.

34 Smith RD, Fineman RM, Myers GG. Short stature, psychomotor retardation, and unusual facial appearance in two brothers. Am $\mathcal{f}$ Med Genet 1980;7:5-9.

35 Davis JG, Silverberg G, Williams MK, Spiro A, Shapiro LR. A new X-linked recessive mental retardation syndrome with progressive spastic quadriparesis. Am $\mathcal{f} \mathrm{Hum}$ Genet 1981;3:75A

36 Schimke RN, Horton WA, Collins DL, Therou L. A new $\mathrm{X}$-linked syndrome comprising progressive basal ganglion dysfunction, mental and growth retardation, external ophthalmoplegia, postnatal microcephaly and deafness. Am $\mathcal{f}$ Med Genet 1984;17:323-32

37 Opitz JM, Richieri-da Costa A, Aase JM, Benke PJ. FG syndrome update 1988. Note of 5 new patients and bibliography. Am $\mathcal{f}$ Med Genet 1988;30:309-28.

38 Pallister PD, Herrmann J, Spranger JW, Gorlin RJ, Langer LO, Opitz JM. The W syndrome. Birth Defects $1974 ; \mathbf{X}(7): 51-60$.
39 Carpenter NJ, Waziri M, Miles J, Patil SR. Studies on Xlinked mental retardation: evidence for a gene in the region Xq11-q22. Am $\mathcal{f}$ Hum Genet 1988;43:139A

40 Sutherland GR, Gedeon AK, Haan EA, Woodroffe P Mulley JC. Linkage studies with the gene for X-linked syndrome of mental retardation, microcephaly and spastic diplegia (MRX2). Am ₹ Med Genet 1988;30:493-508.

41 Sammans C, Albrecht R, Neugebauer M, Neri G, Gal A. Gene for non-specific X-linked mental retardation maps in the pericentromeric region. $A m \mathcal{F}$ Med Genet 1991;38:224-7.

42 Arveiler B, Alembik Y, Hanauer A, et al. Linkage analysis suggests at least two loci for $\mathrm{X}$-linked nonspecific mental retardation. Am $\mathcal{f}$ Med Genet 1991;30:473-83.

43 Suthers GK, Turner G, Mulley JC. A non-syndromal form of X-linked mental retardation (XLMR) is linked to of X-linked mental retardation (XLMR)

44 Neuhauser G, Zerbin-Rudin E. Oligophrenie mit wahrscheinlich geschlechtsgebunden-rezessiver veterbung. cheinlich geschlechtsgebunden
Deutsche Med 1969;94:2519-20.

45 Partington MW, Mulley JC, Sutherland GR, et al. Xlinked mental retardation with dystonic movements of the hands. Am $\mathcal{f}$ Med Genet 1988;30:251-62.

46 Wieacker P, Wolff G, Wienker TF, Sauer M. A new Xlinked syndrome with muscle atrophy, congenital contractures, and oculomotor apraxia. Am $\mathcal{F}$ Med Genet 1985;20:597-606.

47 Paul R, Dykens E, Leckman JF, et al. A comparison of language characteristics of mentally retarded adults with fragile $\mathrm{X}$ syndrome and those with nonspecific mental retardation and autism. I Autism Dev Disorders 1987;17:457-68.

48 Lehrke R. A theory of X-linkage of major intellectual traits. Am F Ment Defic 1972;76:611-9.

49 Einfeld SL. Autism and fragile X syndrome. $\mathrm{Am} \mathrm{f} \mathrm{Med}$ Genet 1988;30:237-8. 